\title{
P53 Gene: Mutation and Immunohistochemical Analysis in Patients with Invasive Ductal Carcinoma of Breast
}

\author{
${ }^{1}$ Shinjini Singh, ${ }^{2}$ Sandeep Kumar Rajput, ${ }^{1}$ Mritunjai Singh, ${ }^{3}$ Pravas Kumar Misra, \\ ${ }^{4}$ Gyanendra Mohan, ${ }^{5}$ Mohan Kumar, ${ }^{2}$ Rakesh Kumar Singh and ${ }^{1}$ Indrajeet Singh Gambhir \\ ${ }^{1}$ Department of Medicine, Institute of Medical Sciences, Banaras Hindu University, Varanasi, 221005, India \\ ${ }^{2}$ Department of Biochemistry, Faculty of Science, Banaras Hindu University, Varanasi, India \\ ${ }^{3}$ Cancer Research Institute, N. E. Railways, Lehertara, Varanasi, India \\ ${ }^{4}$ Department of Pathology, Cancer Research Institute, N. E. Railways, Lehertara, Varanasi, India \\ ${ }^{5}$ Department of Pathology, Institute of Medical Sciences, Banaras Hindu University, Varanasi, India
}

Received 2012-10-23; Revised 2013-10-04; Accepted 2013-10-24

\begin{abstract}
The p53 tumor suppressor gene is the most commonly mutated gene in cancer. In breast cancer, the presence of $\mathrm{p} 53$ gene alterations has been associated with worse prognosis. This study was attempted to associate p53 gene mutations with its protein expression in North Eastern Indian population. We used single-stranded conformation polymorphism to screen samples for mutations in five conserved regions, exons 4, 5, 6, 7 and 8, of the p53 gene. Mutations were confirmed by direct DNA sequencing. Samples were also analyzed for expression of p53 immunohistochemically. We found two critical mutations in the exon 4. A well known missense mutation at codon 72 (pro to arg) with a frequency of $47 \%$ was found which was significantly correlated with the immunohistochemical analysis of p53 protein in such patients. A novel nonsense mutation at codon 107 which leads to stop codon was also found. Although the occurrence of this mutation was very less, we did not find expression of p53 protein immunohistochemicaly. We support that mutation in $\mathrm{p} 53$ gene can be exploited as a prognostic marker for the early diagnosis of breast cancer, although more clinical and epidemiological data is required to establish this claim.
\end{abstract}

Keywords: Breast Cancer, p53, ER, PR, HER2

\section{INTRODUCTION}

In the light of the existing literature breast cancer is the most prevalent cancer among women and affects approximately 1 million women worldwide each year comprising $18 \%$ of all female cancers (Baum, 2002). Several epidemiological studies have documented extensively for the incidence of breast cancer in Indian scenario (Badwe et al., 1990; Jussawalla et al., 1980; 1985; 1998; Kapoor et al., 1993). One in fifty eight women are affected by breast cancer in the age group of
30-70 years and are mainly seen in the urban areas. The well established epidemiological risk factors for the development of the breast cancer are age at diagnosis, family history, parity, age at the menarche and menopause, diet, socioeconomic status, history of exposure to radiation and use of oral contraceptive pills (Helmrich et al., 2009; Dupont and Page, 1985).

In the last decade several lines of evidence have correlated a significant association between the polymorphism of p53 gene and development of breast cancer (Lacroix et al., 2006). p53 plays a key role in Varanasi, 221005, India 
mediating cell response to various stresses, mainly by inducing or repressing a number of genes involved in cell cycle arrest, senescence, apoptosis, DNA repair and angiogenesis. The qualitative and quantitative activity of p53 depends on its integrity (mutation status), its amount and its specific post-translational modifications induced by the activation of the different stress-induced signaling pathways (Lacroix et al., 2006). This leads to variable patterns of association between p53 and a number of other co-regulatory proteins, of which some may be tissue-or cell type-specific. Several association studies between the p53 expression, polymorphism and development of breast cancer have been carried out in various geographical regions of India like Bombay, Eastern Rajasthan, Aligarh, Bangalore, Jammu, Surat and Chennai (Jussawalla et al., 1998; Kapoor et al., 1993; Sharma et al., 1994; Hussain et al., 1994; Nandakumar et al., 1995; Gadhia et al., 1995; Juneja et al., 1990; Lin et al., 2001; Nayak and Das, 1997; 1999a; 1999b; Nayak et al., 1996; 1998; Kannan et al., 2000; Keasri et al., 1997), In continuation, the present study was designed to explore three specific issues of p53 in the subjects suffering from Invasive Ductal Carcinoma (IDC) of breast among middle North-Eastern Indian population: (a) Does the exonic region of p53 contain any sequence aberration? (b). Is there any correlation between the mutational analysis of p53 with clinico-pathological data of the subjects? (c) Is there any correlation between the p53 mutation (if any) with expression status of $\mathrm{p} 53$ protein?

\section{MATERIALS AND METHODS}

\subsection{Subject Selection}

A total of 62 (58 females and 4 males) fresh excision biopsies were obtained from the patients of Invasive Ductal Carcinoma with the mean age of 53.35 99.29 years (aged between 33 to 75). All the patients included in the present study were recruited from in patient department of Cancer Research Institute, North Eastern Railways, Lehertara, Varanasi, India, between January 2009 to March 2010 with their prior informed consent and their detailed history was obtained. Patients receiving chemotherapy and radiotherapy were excluded from the study. Study was approved by the institutional ethical committee.

\subsection{Sample Collection}

Tumor biopsies were collected directly from the surgical operation theater of the department of oncology in chilled phosphate-buffered saline from the patients who underwent mastectomy. Each freshly microdissected tumor was divided into two equal portions by use of a disposable scalpel. Slices were taken from the outer, viable, cellular region of one half for later DNA analysis and sequencing. Corresponding slices from the other half taken in $10 \%$ formalin were prepared for histopathological examination. The part of the tumor that was frozen was stored at $-80^{\circ} \mathrm{C}$ until analysis. The adjacent tissue biopsy from each individual was taken as control.

\subsection{DNA Isolation}

Cellular DNA from collected breast tumor biopsies was isolated using standard proteinase $\mathrm{K}$ digestion, phenol-chloroform extraction and ethanol precipitation method routinely being used in our laboratory (Sambrook and Russell, 2001). The quality and concentration of DNA was measured on an ethidium bromide-stained $1 \%$ agarose gel and by standard spectrophotometric methods.

\subsection{Polymerase Chain Reaction}

Approximately, 100-200 ng DNA was utilized for conventional PCR using the protocol routinely followed in our laboratory. Briefly, the method involved a $50 \mu \mathrm{L}$ reaction mix containing 100-200 ng DNA, 5.0 $\mu \mathrm{L}$ of 10X PCR buffer, $3.0 \mu \mathrm{L}$ of $25 \mathrm{Mm} \mathrm{MgCl} 2,0.5 \mu \mathrm{L}$ of $10 \mathrm{Mm}$ dNTPs, $0.5 \mu \mathrm{L}$ of $10 \mathrm{pmol}$ forward primer, 0.5 $\mu \mathrm{L}$ of 10 pmol reverse primer, $0.5 \mu \mathrm{L}$ of Taq DNA polymerase $\left(1 \mathrm{U} \mu \mathrm{L}^{-1}\right)$. The PCR primers for exonic regions ( 4 to 8 ) of p53 used for amplification have been mentioned in Table 1.

\subsection{Single-Strand Conformation Polymorphism Analysis}

Single-Strand Conformation Polymorphism (SSCP) analysis was performed as described by Michaelides et al. (1995). Depending on the PCR product concentration, $4 \pm 1.2 \mathrm{~mL}$ of the PCR product was added to the same volume of denaturing solution containing $800 \mu \mathrm{L}$ formamide, $100 \mu \mathrm{L}$ of $1 \%$ Bromophenol Blue, $100 \mu \mathrm{L}$ of $1 \%$ xylene cyanol, $2 \mu \mathrm{L}$ of $0.5 \mathrm{M}$ EDTA and $1 \mu \mathrm{L}$ of 10 $\mathrm{M} \mathrm{NaOH}$ per $1 \mathrm{~mL}$ solution. Samples were denatured at $93^{\circ} \mathrm{C}$ for $5 \mathrm{~min}$ and transferred immediately to ice to prevent renaturation of DNA. Each sample was loaded onto a $10 \%$ polyacrylamide gel with $0.5 \mathrm{~mm}$ thickness. Electrophoresis was performed in $1 \mathrm{X} \mathrm{TBE}$ at $4{ }^{\circ} \mathrm{C}$ and at $19 \mathrm{~mA}$ for 5 to $7 \mathrm{~h}$ depending on the size of the PCR product. Each PCR product was electrophoresed at least three times to increase precision and to prevent false positive results. Bands were visualized after silver staining of gel, as described (Bourn et al., 1994). 
Table 1. Primers used in amplification of exons 4 to 8 of $\mathrm{p} 53$ gene

\begin{tabular}{|c|c|}
\hline p53 Exon & $\begin{array}{l}\text { Primer sequence } \\
\mathrm{F}=\text { Forward Primer, } \mathrm{R}=\text { Reverse primer }\end{array}$ \\
\hline \multirow[t]{2}{*}{4} & $\begin{array}{ll}\mathrm{F} & \text { TGACTGCTCTTTTCACCCAT }\end{array}$ \\
\hline & R GGAAGCCAGCCCCTCAGGGC \\
\hline \multirow[t]{2}{*}{5} & F TGTTCACTTGTGCCCTGACT \\
\hline & R CAGCCCTGTCGTCTCTCCAG \\
\hline \multirow[t]{2}{*}{6} & F GCCTCTGATTCCTCACTGAT \\
\hline & TTAACСССТССТCCCAGAGA \\
\hline \multirow[t]{2}{*}{7} & ACTGGCCTCATCTTGGGCCT \\
\hline & $\mathrm{R}$ TGTGCAGGGTGGCAAGTGGC \\
\hline \multirow[t]{2}{*}{8} & TAAATGGGACAGGTAGGACC \\
\hline & TCCACCGCTTCTTGTCCTGC \\
\hline
\end{tabular}

\subsection{Sequencing}

Purified PCR products of the samples showing mobility shift on SSCP analysis and randomly chosen samples were sent for sequencing. Direct DNA sequencing using an automated ABI 3100 Genetic Analyzer (Bangalore Genei) using ABI's AmpliTaq FS dye terminator cycle sanger's sequencing chemistry.

\subsection{Sample Processing for Histology and Analysis}

Paraffin-embedded tumor sections on poly-L-lysine coated slides were dewaxed in xylene and rehydrated in ethanol and distilled water. Antigen retrieval in a microwave oven at $750 \mathrm{~W}$ (two cycles for 10 minutes each) enhanced p53 antigen accessibility to antibodies. The expression of Estrogen Receptor (ER), Progesterone Receptor (PR) and HER2 (Human Epidermal growth factor Receptor-2) were also checked using specific antibodies. Positive p53 IHC staining was seen in the nucleus of cancer cells. IHC-positive samples were subclassified with regard to immunostaining intensity and extent according to graded scales that ranged from 1 to 3 . Allred's method was used for the scoring of p53, ER and PR and for HER2 expression, Hercep Test; DAKO was used (Allred et al., 1990; Dako and Hoffman, 2002). Super sensitive polymer-HRP detection system and primary antibodies p53, ER, PR and HER2 from Biogenex, CA, USA were used. All slides were viewed and judged microscopically by the pathologist.

\subsection{Statistical Analysis}

Analysis was performed with the Statistical Package for Social Science (SPSS) windows version 16. Chisquare test was used to compare the frequencies. Statistical significance was considered when $\mathrm{p} \leq 0.05$.

\section{RESULTS}

Clinico-pathological features of the recruited patients are presented in Table 2. Most of the patients at diagnosis were either in tumor stage II $(75.1 \%)$ or in stage III (24.1\%). All patients underwent mastectomy.

Sequencing of amplified p53 exons (4 to 8) from all the recruited subjects were carried out to confirm the mobility shift bands detected on SSCP gel. Out of 62 patients, we found 29 subjects with p53 mutations. Table 3 summarizes the age wise frequency of patients with and without p53 mutations. We found 2 critical mutations in the exon 4 at codon positions 72 and 107 resulting in the missense and nonsense mutations, respectively (Fig. 1) as compared to the corresponding controls. Table 4 represents a summary of p53 gene mutations in breast cancer patients. No sequence aberration was found in exons 5, 6, 7 and 8 in the patients with respect to their corresponding control biopsies. The sequencing results were further confirmed by Single-strand conformation polymorphism analysis also (Fig. 2). The nonsense mutation at codon 107 occurred along with the missense one at codon 72 . To search for suitable mutations of p53 gene PCR-SSCP analysis was used as a screening technique.

All the mutated and wild type sequences were submitted to NCBI and the accession numbers obtained were as follows: exon 4 (wild type): BankIt1451832 Seq1 JF923567, exon 4 (mutation A): BankIt1451832 Seq2 JF923568, exon 4 (mutation B): BankIt1451832 Seq3 JF923569, exon 5: BankIt1451832 Seq4 JF923570, exon 6: BankIt1451832 Seq5 JF923571, exon 7: BankIt1451832 Seq6 JF923572 and exon 8: BankIt1451832 Seq7 JF923573.

Table 5 summarizes the frequency of p53 mutation positive patients and their clinicopathological features. Menopausal status $(\mathrm{p}=0.013)$, histological grade $(\mathrm{p}=$ $0.048)$ and axillary lymph node involvement $(p=0.018)$ were found to be significantly associated with the p53 mutation positive cases.

Out of 62 biopsies from patients, 27 were found to be p53 positive, further immunohistochemical analysis revealed a significant higher expression of $\mathrm{p} 53$ protein in the breast cancer biopsies as compared to their corresponding control biopsies (Fig. 3). A total of 51 $(82.0 \%)$ tumors were found negative for ER, $54(87.0 \%)$ tumors were found negative for PR and $44(71.0 \%)$ were found positive for HER2 membrane staining. Interestingly we did not find the expression of p53 in the 2 patients having nonsense mutation. Table 6 summarizes the age wise frequency of patients with p53 expression. Correlation of menstrual status with $\mathrm{p} 53$ expression and HER2 expression was found to be significant, their $p$ values being 0.031 and $<0.001$, respectively. 


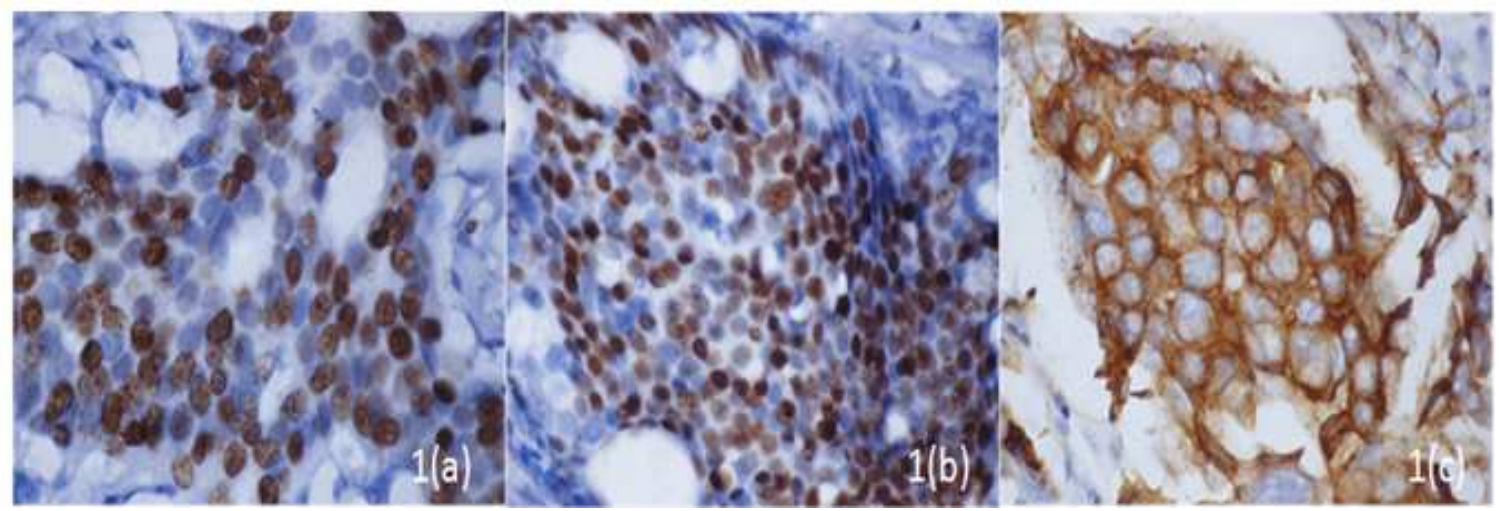

Fig. 1. Immunohistochemical staining of ER(1a), PR(1b) and HER2(1c) at $400 \mathrm{X}$

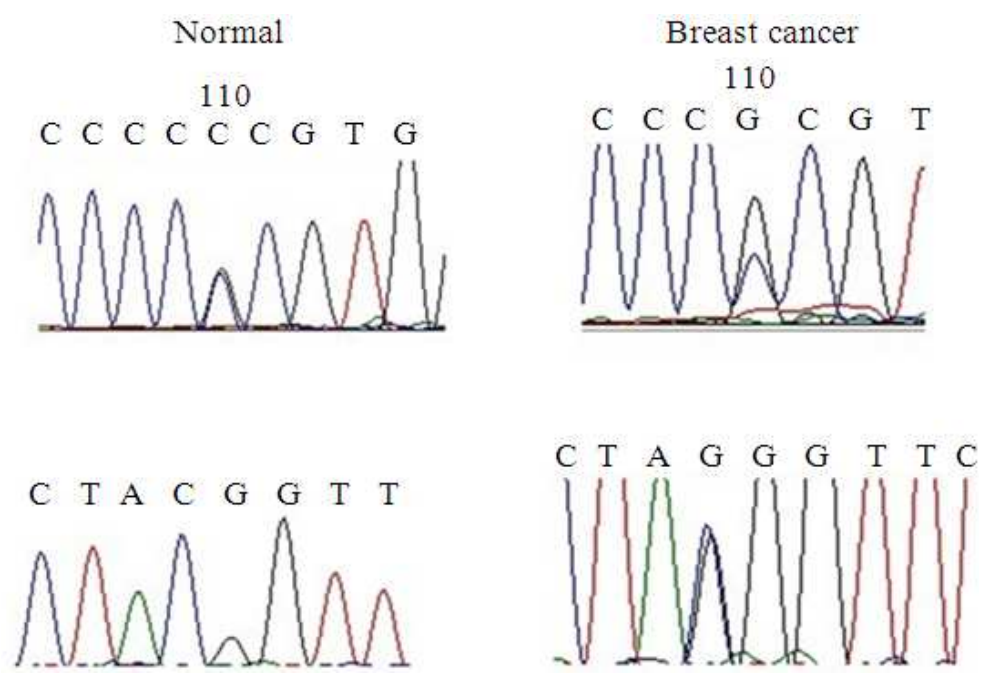

Fig. 2. Representative partial electropherograms of sequencing results showing two critical mutations in the exon 4 of p53 gene

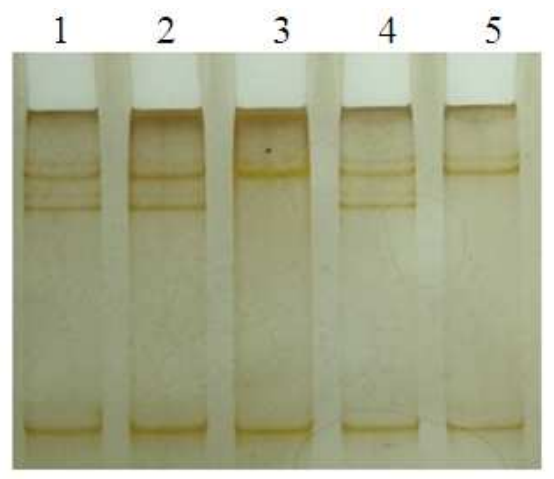

Tumor biopsy

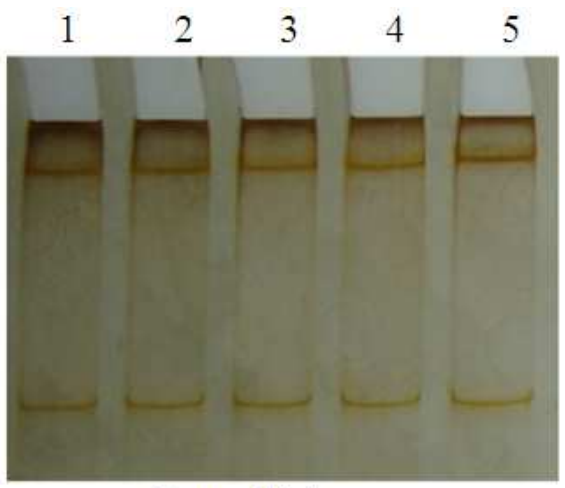

Control biopsy

Fig. 3. Detection of mutations in exon 4 of p 53 gene. $10 \%$ polyacrylamide gel picture showing the electrophoretic mobility shift of p53 exon 4 from various tumor biopsies as compared to their normal biopsies. Samples 1, 2 and 4 are showing the genetic aberration 
Table 2. Clinicopathological features of the breast cancer patients

\begin{tabular}{|c|c|c|}
\hline \multicolumn{2}{|c|}{ - } & $\mathrm{N}$ [Value (\%)] \\
\hline \multirow[t]{2}{*}{ Breast Side } & Left & $32 / 62(51.6)$ \\
\hline & Right & $30 / 62(48.3)$ \\
\hline \multirow[t]{2}{*}{ Menstrual Status } & Pre menopausal & $18 / 58(31.0)$ \\
\hline & Post menopausal & 40/58 (68.9) \\
\hline \multirow[t]{2}{*}{ Age at menarche } & $\leq 13$ years & $22 / 58(37.9)$ \\
\hline & $>13$ years & $34 / 58(58.6)$ \\
\hline \multirow[t]{3}{*}{ Parity } & Nulliparous & $9 / 58(15.5)$ \\
\hline & 1-4 Children & $35 / 58(60.3)$ \\
\hline & $>4$ children & $14 / 58(24.1)$ \\
\hline Lifetime duration & $<36$ months & $24 / 58(41.3)$ \\
\hline \multirow[t]{3}{*}{ of breast feeding } & $36-54$ months & $12 / 58(20.6)$ \\
\hline & $55-78$ months & $10 / 58(17.2)$ \\
\hline & $>78$ months & $12 / 58(20.6)$ \\
\hline \multirow{2}{*}{ Pagets`s Disease } & Yes & $4 / 62(6.4)$ \\
\hline & No & $58 / 62(93.5)$ \\
\hline \multirow[t]{3}{*}{ Tumor Stage } & $\mathrm{T} 2$ & $0 / 62(0)$ \\
\hline & T3 & $36 / 62(58.0)$ \\
\hline & T4 & 26/62 (41.9) \\
\hline \multirow[t]{3}{*}{ Histological Grade } & Grade I & $0 / 62(0)$ \\
\hline & Grade II & $47 / 62(75.8)$ \\
\hline & Grade III & $15 / 62(24.1)$ \\
\hline No. of Axillary & 0 & $18 / 62(12.9)$ \\
\hline \multirow[t]{2}{*}{ Lymph Nodes } & $1-3$ & $27 / 62(43.5)$ \\
\hline & $>3$ & $17 / 62(27.4)$ \\
\hline
\end{tabular}

Table 3. Summary of p53 mutations in breast cancer patients

\begin{tabular}{|c|c|c|c|c|}
\hline \multirow[b]{2}{*}{ Age (years) } & \multicolumn{2}{|c|}{ p53 Positive } & \multicolumn{2}{|c|}{ p53 Negative } \\
\hline & Number & Percentage & Number & Percentage \\
\hline$\leq 50$ & $11 / 62$ & 17.7 & $16 / 62$ & 25.8 \\
\hline$>50$ & $18 / 62$ & 29.0 & $17 / 62$ & 27.4 \\
\hline
\end{tabular}

Table 4. Nature of $\mathrm{p} 53$ mutations in sporadic breast cancer patients

\begin{tabular}{lllllll}
\hline No. of patients & $\begin{array}{l}\text { Exon containing } \\
\text { mutation }\end{array}$ & $\begin{array}{l}\text { Codon } \\
\text { Number }\end{array}$ & $\begin{array}{l}\text { Nucleotide } \\
\text { Number }\end{array}$ & Base Change & $\begin{array}{l}\text { Amino Acid } \\
\text { Change }\end{array}$ & $\begin{array}{l}\text { Types of } \\
\text { mutation }\end{array}$ \\
\hline 29 & 4 & 72 & 1138 & CCC $\rightarrow$ CGC & Pro $\rightarrow$ Arg & Missense \\
2 & 4 & 107 & 1149 & TAC $\rightarrow$ TAG & Tyr $\rightarrow$ Stop & Nonsense \\
\hline
\end{tabular}

Table 5. Patients' characteristics and clinic pathological features of p53 mutants.

\begin{tabular}{|c|c|c|}
\hline \multicolumn{2}{|c|}{ 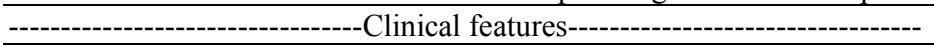 } & p53 mutants $n(\%)$ \\
\hline \multirow[t]{2}{*}{ Age (years) } & $\leq 50$ & 11/29 (37.9) \\
\hline & $>50$ & 18/29 (62.0) \\
\hline \multirow[t]{2}{*}{ Residence } & Rural & $2 / 29(6.8)$ \\
\hline & Urban & $27 / 29(51.7)$ \\
\hline \multirow[t]{2}{*}{ Menopausal Status } & Pre & $11 / 25(44.0)$ \\
\hline & Post & $18 / 25(72.0)$ \\
\hline \multirow[t]{2}{*}{ Breast involved } & Right & $10 / 29(34.4)$ \\
\hline & Left & 19/29 (65.5) \\
\hline \multirow[t]{2}{*}{ Provisional Diagnosis } & IDC & $29 / 29(100)$ \\
\hline & Paget`s disease & $2 / 29(6.8)$ \\
\hline \multirow{2}{*}{ Lymph Nodes involved } & Yes & $19 / 29(65.5)$ \\
\hline & No & 10/29 (34.4) \\
\hline \multirow[t]{3}{*}{ Histological Grade } & Grade I & $0(0)$ \\
\hline & Grade II & $22 / 29(75.8)$ \\
\hline & Grade III & $7 / 29(24.1)$ \\
\hline \multirow[t]{3}{*}{ Clinical Tumor Stage } & $\mathrm{T} 2$ & $0(0)$ \\
\hline & T3 & $17 / 29(58.6)$ \\
\hline & $\mathrm{T} 4$ & $12 / 29(41.3)$ \\
\hline
\end{tabular}


Table 6. Summary of the age wise frequency of patients with p53 expression p53 IHC status

\begin{tabular}{lllll} 
& & & & \\
Age (years) & Negative $[\mathrm{n}(\%)]$ & $+1[\mathrm{n}(\%)]$ & $+2[\mathrm{n}(\%)]$ & $+3[\mathrm{n}(\%)]$ \\
\hline$\leq 50$ & $16 / 62(25.8)$ & $0 / 62(0)$ & $1 / 62(1.6)$ & $9 / 62(14.5)$ \\
$>50$ & $3 / 62(4.8)$ & $9 / 62(14.5)$ & $1 / 62(1.6)$ & $18 / 62(29.0)$ \\
\hline
\end{tabular}

Tumor size was found to be significantly associated with ER negativity $(\mathrm{p}=0.015)$, histological grade was found to be significantly associated with $\mathrm{p} 53$ expression $(\mathrm{p}=$ 0.018) and ALN involvement was also found to be significantly associated with p53 expression (0.025).

\section{DISCUSSION}

p53, a well established tumor suppressor gene has the centre of attraction for the researchers in the field of cancer biology for its ability to regulate several fundamental cellular processes like cell cycle arrest, senescence, apoptosis, DNA repair and angiogenesis (Lacroix et al., 2006). The status of p53 in human breast cancer has been the subject of intensive investigation (Gasco et al., 2002; Anne-Lise, 2003). The presence of mutation, with or without accompanying Loss of Heterozygosity ( $\mathrm{LOH})$, was an early finding in cell lines and primary breast cancers, establishing p53 as a bona-fide tumor suppressor gene in the breast. Epidemiological studies have documented extensively the incidence of breast cancer in the western population (Ursin et al., 1994) but the available information in India is limited. India is a vast sub-continent with a huge population of multiracial society with widely varying cultures and several ethnic groups. Different aspects of breast cancer involving epidemiology, risk factors and susceptibility have been dealt in various communities and regions. Some association studies between the p53 expression, polymorphism and development of breast cancer have been carried out in various geographical regions of India like Bombay, Eastern Rajasthan, Aligarh, Bangalore, Jammu, Surat, Chennai (Jussawalla et al., 1998; Kapoor et al., 1993; Sharma et al., 1994; Hussain et al., 1994; Nandakumar et al., 1995; Gadhia et al., 1995; Juneja et al., 1990; Lin et al., 2001; Nayak and Das, 1997; 1999a; 1999b; Nayak et al., 1996; 1998; Kannan et al., 2000; Keasri et al., 1997). The present study is an extension of these Indian studies for the geographically distinct middle north eastern population in order to explore the sequence aberration in p53 gene and its protein expression as well as correlation with demographic and clinical findings.

Our study comprised of 62 subjects with confirmed diagnosis of IDC of breast. Association of the p53 mutation was found significant with gender postmenopausal status, histological grade and ALN involvement which was consistent with existing data in the literature (Giordano et al., 2004; Cutler et al., 2009; Madigan et al., 1995). Our sequencing data revealed p53 gene mutations in 29 (47\%) tumor biopsies from different individuals. We observed two critical mutations in the exonic region 4 of p53 (Fig. 2 and 3 ). The missense mutation at codon 72 (pro to Arg) has been shown to have varying ethnic and geographical distribution (Chosdol et al., 2002; Ihsan et al., 2011; Kalemi et al., 2005). The frequency of this mutation in our breast cancer population was found to be around $50 \%$. It has already been reported that the p53 Arg homozygous genotype could be a potential genetic risk factor for cancer (Buyru et al., 2003; Papadakis et al., 2000). Further our mutation data was correlated with the immunohistochemical analysis of significant high expression of p53 protein (Fig. 4). In healthy humans, the p53 protein is continually produced and degraded in the cell. The degradation of the p53 protein is associated with MDM2 binding. In a negative feedback loop, MDM2 is itself induced by the p53 protein (Haupt et al., 1997). However, mutant p53 protein often does not induce MDM2 and is thus able to accumulate at very high concentrations (Peng et al., 2001) and hence detectable by IHC. We reported another novel nonsense mutation at codon 107 which leads to the stop codon. Although the occurrence of this mutation is very less, but interestingly we did not find the expression the p53 protein by histological analysis which supports the translation of truncated p53 protein and ultimately leads to protein degradation (Heck et al., 2010). 


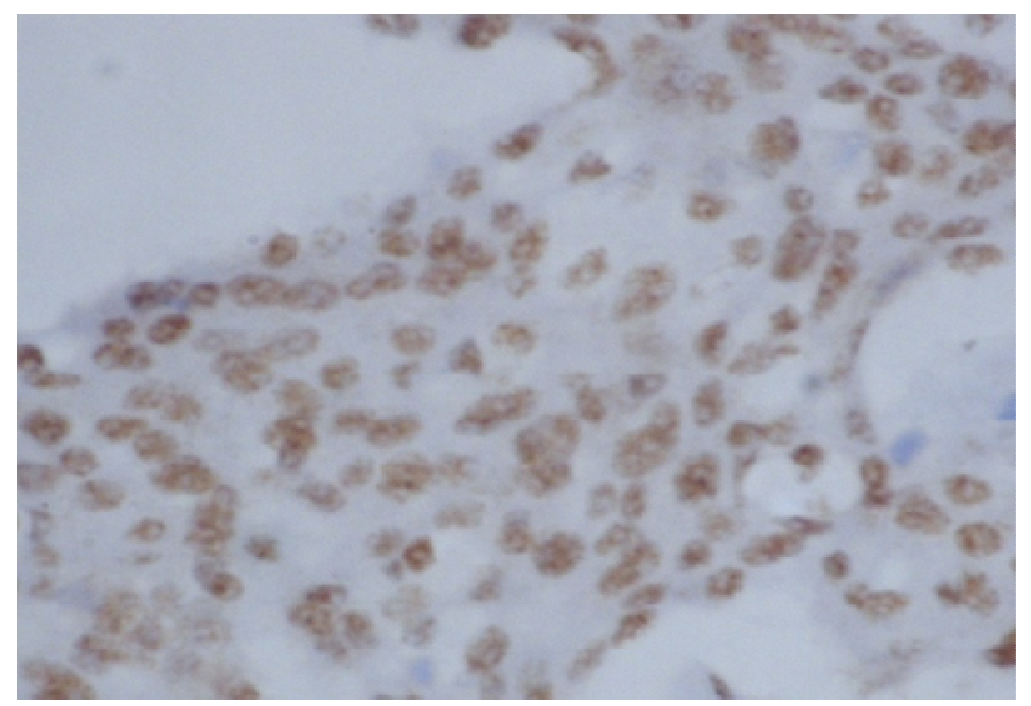

Fig. 4. Immunostaining showing $\mathrm{p} 53$ positivity at $400 \mathrm{X}$

\section{CONCLUSION}

Our data thus indicate that p53 gene can be exploited as a prognostic marker for the early diagnosis of breast cancer, although more clinical and epidemiological data across the Indian and Asian geographical regions is required to establish this claim.

\section{ACKNOWLEDGMENT}

We are indebted to all the patients and their family members who participated in this study. We would like to thank the nurses and the O.T. staff for helping us during the sample collection from the mastectomized tissues.

\section{REFERENCES}

Allred, D.C., M.A. Bustamante and C.O. Daniel, 1990. Immunocytochemical analysis of estrogen receptors in human breast carcinomas: Evaluation of 130 cases and review of the literature regarding concordance with biochemical assay and clinical relevance. Arch. Surg., 125: 107-113. DOI: 10.1001/archsurg.1990.01410130113018

Anne-Lise, B., 2003. TP53 and breast cancer. Hum Mutat., 21: 292-300. DOI: 10.1002/humu.10174

Badwe, R.A., S. Gangawal, I. Mittra and P.B. Desai, 1990. Clinico-pathological features and prognosis of breast cancer in different religious communities in India. Indian J. Cancer, 27: 220-228. PMID: 2090578
Baum, M., 2002. The changing face of breast cancer-past, present and future perspectives. Breast Cancer Res. Treat., 75: S33-S35. PMID: 12353817

Bourn, D., S.A. Carter, S. Mason, D.Gareth and R. Evans et al., 1994. Germline mutations in the neurofibromatosis type 2 tumour suppressor gene. Hum. Mol. Genet., 3: 813-816. PMID: 8081368

Buyru, N., H. Tigli and N. Dalay, 2003. P53 codon 72 polymorphism in breast cancer. Oncol. Rep., 10: 711-714. PMID: 12684648

Chosdol, K., A. Ahuja, A. Rathore, M. Anjan and H.M. Syed et al., 2002. Study of p53 codon 72 polymorphism in various ethnic groups of North India. Curr. Sci., 82: 1253-1255.

Cutler, W.B., R.E. Burki, E. Genovesse, F. Penn and M.G. Zacher et al., 2009. Breast cancer in postmenopausal women: what is the real risk? Fertil Steril, 92: 1S16-1S16.

Dako and F. Hoffman, 2002. Hercep Test Interpretation Manual-Breast. La Roche Ltd. Dako, USA.

Dupont, W.D. and D.L. Page, 1985. Risk factors for breast cancer in women with proliferative breast disease. N. Engl. J. Med., 312: 146-151. DOI: 10.1056/NEJM198501173120303

Gadhia, P.K., N.D. Panchal and S.V. Bhagwat, 1995. Cancer profile in Surat and its vicinity. J. Indian Med. Assoc., 93: 101-102. PMID: 8522804

Gasco, M., S. Shami and T. Crook, 2002. The p53 pathway in breast cancer. Breast Cancer Res., 4: 7070. DOI: $10.1186 /$ bcr 426 
Giordano, S.H., D.S. Cohen, A.U. Buzdar, G. Perkins and G.N. Hortobagyi, 2004. Breast carcinoma in men. Cancer, 101: 51-57. DOI: 10.1002/cncr.20312

Haupt, Y., R. Maya, A. Kazaz and M. Oren, 1997. Mdm2 promotes the rapid degradation of $\mathrm{p} 53$. Nature, 15: 296-299. DOI: 10.1038/387296a0

Heck, J.H., S.K. Cheung and R.Y. Hampton, 2010. Cytoplasmic protein quality control degradation mediated by parallel actions of the E3 ubiquitin ligases Ubr1 and San1. PNAS, 107: 1106-1111. DOI: 10.1073/pnas.0910591107

Helmrich, S.P., S. Shapiro and L. Rosenberg, 2009. Risk Factors for breast cancer. Am. J. Epidemiol., 117: 135-145.

Hussain, M.A., S. Ali, S.P. Tyagi and H. Reza, 1994. Incidence of cancer breast at Aligarh. J. Indian Med. Assoc., 92: 296-297. PMID: 7814903

Ihsan, R., T.R. Devi, D.S. Yadav, A.K. Mishra and J. Sharma et al., 2011. Investigation on the role of p53 Codon 72 polymorphism and interactions with tobacco, betel quid and alcohol in susceptibility to cancers in a high-risk population from North East India. DNA Cell Biol., 30: 163-171. DOI: 10.1089/dna.2010.1119

Juneja, A., N.S. Murthy, A. Sehgal, A.K. Prabhakar and U.K. Luthra, 1990. Risk for development of cancer in three urban areas of India. Neoplasma, 37: 483488. PMID: 2234209

Jussawalla, D.J., B.B. Yeole and M.V. Natekar, 1985. Cancer in Indian Moslems. Cancer, 55: 1149-1158. DOI: $10.1002 / 1097-$ 0142(19850301)55:5<1149::AIDCNCR2820550534>3.0.CO;2-D

Jussawalla, D.J., B.B. Yeole and M.V. Natekar, 1998. Histological and epidemiological features of breast cancer in different religious groups in greater Bombay. J. Surg. Oncol., 18: 269-279. DOI: 10.1002/jso.2930180309

Jussawalla, D.J., B.B. Yeole, M.V. Natekar and T.R. Rajagopalan, 1980. Cancer in the Sindhi population of greater Bombay. Cancer, 46: 2107-2115. DOI: 10.1002/1097-0142(19801101)46:9<2107::AIDCNCR2820460933>3.0.CO;2-T

Kalemi, T.G., A.F. Lambropoulos, M. Gueorguievb, S. Chrisafi and K.T. Papazisis et al., 2005. The association of p53 mutations and p53 codon 72, Her 2 codon 655 and MTHFR C677T polymorphisms with breast cancer in Northern Greece. Cancer Lett., 222: 57-65. DOI: 10.1016/j.canlet.2004.11.025
Kannan, K., J. Krishnamurthy, J. Feng, T. Nakajima and $\mathrm{N}$. Tsuchida et al., 2000. Mutation profile of the p53, fhit, p16INK4a/p19ARF and H-ras genes in Indian breast carcinomas. Int. J. Oncol., 17: 10311035. PMID: 11029509

Kapoor, R., K.C. Goswami, B. Kapoor and V.K. Dubey, 1993. Pattern of cancer in Jammu region (hospital based study 1978-'87). Indian J. Cancer, 30: 67-71. PMID: 8225379

Keasri, A.L., V.G. Chellam, P.P. Nair, I. Ahmed and J. Madhavan et al., 1997. p53 tumor suppressor protein and tissue proliferative fraction in infiltrating duct carcinoma. J. Surg. Oncol., 65: 159-166. DOI: 10.1002/(SICI)1096-9098(199707)65:3<159::AID$\mathrm{JSO} 3>3.0 . \mathrm{CO} ; 2-5$

Lacroix, M., R.A. Toillon and G. Leclercq, 2006. p53 and breast cancer, an update. Endocr. Relat. Cancer, 13: 293-325. DOI: 10.1677/erc.1.01172

Lin, J., C. Page, X. Jin, A.O. Sethi and R. Patel et al., 2001. Suppression activity of pro-apoptotic gene products in cancer cells, a potential application for cancer gene therapy. Anticancer Res., 21: 831-839. PMID: 11396172

Madigan, M.P., R.G. Ziegler, J. Benichou, C. Byrne and R.N. Hoover, 1995. Proportion of breast cancer cases in the United States explained by wellestablished risk factors. J. Natl. Cancer Inst., 87: 1681-1685. DOI: 10.1093/jnci/87.22.1681

Michaelides, K., R. Schwaab, M.R.A. Lalloz, 1995. Mutational Analysis: New Mutations. In: PCR 2: A Practical Approach, McPherson, M.J. and B.D. Hames (Eds.), IRL Press, Oxford, ISBN-10: 0199634246, pp: 2552-2588.

Nandakumar, A., N. Anantha, T.C. Venugopal, R. Sankaranarayanan and K. Thimmasetty et al., 1995. Survival in breast cancer: A population-based study in Bangalore, India. Int J., Cancer, 60: 593-596. DOI: $10.1002 /$ ijc. 2910600504

Nayak, B.K. and B.R. Das, 1997. Differential binding of nuclear proteins to the TP53 gene promoter in male breast tumour. Eur. J. Cancer, 33: 1484-1487. DOI: 10.1016/S0959-8049(97)00164-0

Nayak, B.K. and B.R. Das, 1999a. Differential binding of NF1 transcription factor to P53 gene promoter and its depletion in human breast tumours. Mol. Biol. Rep., 26: 223-230. DOI: 10.1023/A:1007006011253

Nayak, B.K. and B.R. Das, 1999b. Mutation and methylation status of p53 gene promoter in human breast tumours. Tumour Biol., 20: 341-346. DOI: $10.1159 / 000030098$ 
Nayak, B.K., R.N. Baral and B.R. Das, 1996. p53 gene mutation in relation to $\mathrm{p} 53$ protein accumulation in male and female breast cancer. Neoplasma, 43: 305310. PMID: 8996549

Nayak, B.K., S. Patnaik and B.R. Das, 1998. Rearrangement of the p53 gene in human breast tumours. Biochem. Biophys. Res. Commun., 245: 388-391. DOI: 10.1006/bbrc.1998.8444

Papadakis, E.N., D.N. Dokianakis and D.A. Spandidos, 2000. P53 codon 72 polymorphism as a risk factor in the development of breast cancer. Mol. Cell Biol. Res. Commun., 3: 389-392. DOI: 10.1006/mcbr.2000.0241
Peng, Y., L. Chen, C. Li, W. Lu and J. Chen, 2001. Inhibition of MDM2 by hsp90 contributes to mutant p53 stabilization. J. Biol. Chem., 276: 40583405890. DOI: 10.1074/jbc.M102817200

Sambrook, J. and D.W. Russell, 2001. Molecular Cloning: A Laboratory Manual. 3rd Edn., CSHL Press, Cold Spring Harbor, New York, ISBN-10: 0879695773, pp: 2344.

Sharma, R.G., R. Ajmera and O. Saxena, 1994. Cancer profile in eastern Rajasthan. Indian J. Cancer, 31: 160-173. PMID: 8557294

Ursin, G., L. Bernstein and M.C. Pike, 1994. Breast cancer. Cancer Surv, 19-20: 241-264. 